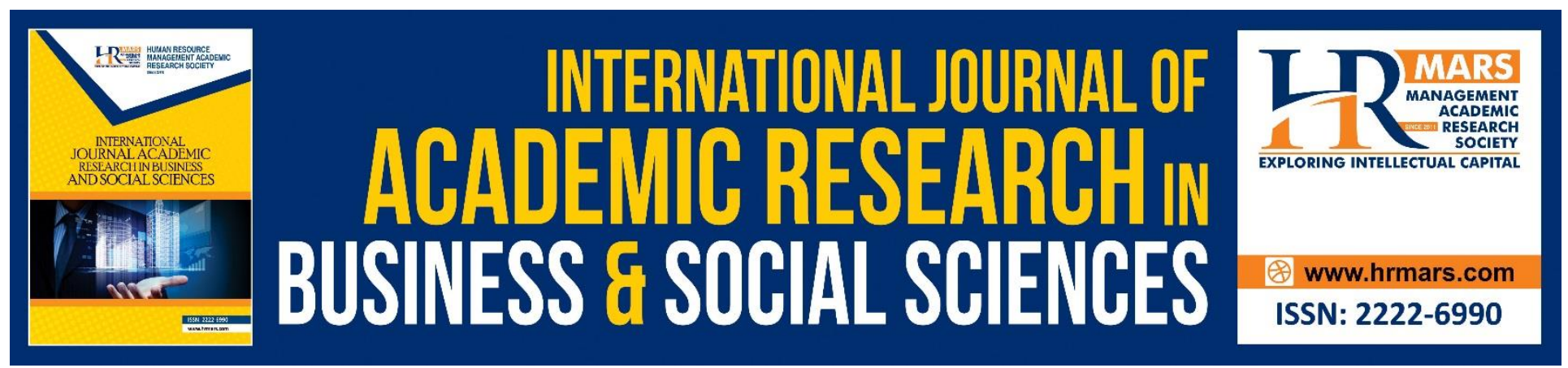

\title{
The Effect of Internal Environmental Factors on Operational Excellence of Manufacturing Industry: A Pilot Study
}

\author{
Mohd Hafeez Al-Amin Abdul Wahab, Mohammad Ismail and Mohd Nazri \\ Muhayiddin
}

To Link this Article: http://dx.doi.org/10.6007/IJARBSS/v9-i2/5666

DOI: $\quad 10.6007 /$ IJARBSS/v9-i2/5666

Received: 17 Jan 2019, Revised: 23 Feb 2019, Accepted: 06 March 2019

Published Online: 09 March 2019

In-Text Citation: (Wahab, Ismail, \& Muhayiddin, 2019)

To Cite this Article: Wahab, M. H. A.-A. A., Ismail, M., \& Muhayiddin, M. N. (2019). The Effect of Internal Environmental Factors on Operational Excellence of Manufacturing Industry: A Pilot Study. International Journal of Academic Research in Business and Social Sciences, 9(2), 1087-1099.

Copyright: @ 2019 The Author(s)

Published by Human Resource Management Academic Research Society (www.hrmars.com)

This article is published under the Creative Commons Attribution (CC BY 4.0) license. Anyone may reproduce, distribute, translate and create derivative works of this article (for both commercial and non-commercial purposes), subject to full attribution to the original publication and authors. The full terms of this license may be seen

at: $\underline{\text { http://creativecommons.org/licences/by/4.0/legalcode }}$

\section{Vol. 9, No. 2, 2019, Pg. 1087 - 1099}




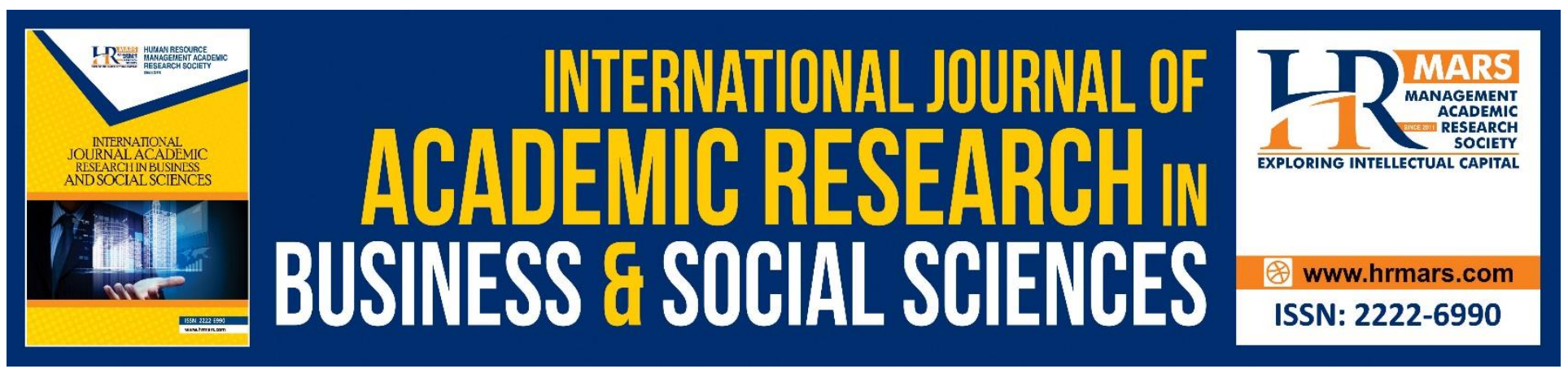

\title{
The Effect of Internal Environmental Factors on Operational Excellence of Manufacturing Industry: A Pilot Study
}

\section{Mohd Hafeez Al-Amin Abdul Wahab, Mohammad Ismail and Mohd Nazri Muhayiddin}

Faculty of Entrepreneurship and Business, Universiti Malaysia Kelantan, Malaysia

\begin{abstract}
This paper examines internal environmental factors that influence the operational excellence of SMEs manufacturing sector in Malaysia. The objective of this paper is to measure the reliability and validity of internal environmental factors and its construct. A pilot study was conducted among 30 SMEs company in Terengganu which represented by the managerial level who are closely linked to the manufacturing operations. This study adopted a survey method by using simple random sampling method for the data collection. The reliability and validity of the instrument were examined through content validity, face validity and reliability based on expert assessment and the data was analyzed using the statistical software SPSS version 22. The result shows that the survey instrument is reliable and valid. Therefore, this study expected will help the Malaysian SMEs manufacturing sector in determining the effect of internal environmental factors on operational excellence.
\end{abstract}

Keywords: Internal Environmental Factors, The Manufacturing Sector, Operational Excellence, Operational Management, Small and Medium Enterprises (Sme).

\section{Introduction}

The business environment today has become more challenging and more complex due to the difference in customer needs, demographics changing, technological advance and the effects of globalization (Bolboli \& Reiche, 2013; Davis, Aquilano, Balakrishnan, \& Chase, 2005). The organization needs to create the ability to respond and adapt to changes caused by uncertain environmental conditions to maintain their competitiveness (Ahmad, 2012; Chen, 2008; Ifeanyichukwu, 2010; Lansiluoto \& Eklund, 2008). To respond actively to survive the challenges in the market conditions, the organizations are required to pursue excellence in their business which will guide the organizations on the right track to attain their objectives and mission (Abdul Wahab, Ismail, \& Muhayiddin, 2016; Jaeger, Matyas, \& Sihn, 2014; Yew \& Ahmad, 2014). Additionally, excellence will 
INTERNATIONAL JOURNAL OF ACADEMIC RESEARCH IN BUSINESS AND SOCIAL SCIENCES Vol. 9, No. 2, Feb, 2019, E-ISSN: $2222-6990$ ๑ 2019 HRMARS

drive the organization to improve constantly to survive and only those who can stay ahead through excellence are well-positioned in the competition (Ekmekci, 2012). One of the ways to achieve excellence is by pursuing operational excellence. Operational excellence is one of the important aspects of business excellence which is an aspect of organizational structure that strives for improvements in key operational performance metrics (Shehadeh, Zu'bi, Abdallah, \& Maqableh, 2016).

Moreover, many organizations today are seeking excellence in their business. All organizations across industries are seeking excellence to improve their performance. However, how to achieve the excellence level and sustained the competitive advantages still the main questions in the business performance. Most of the organizations have not achieved the excellence levels because the management does not have a profound understanding of what is real means to be excellence (Abdul Wahab et al., 2016; Dahlgaard-Park \& Dahlgaard, 2007; Ojha, 2015; Yew \& Ahmad, 2014). Additionally, understanding of the factors that influence operational excellence is one of the issues in pursuing excellence among the organizations. One of the reasons is because the guideline that describes how to achieve the operational excellence is remained unclear (Cesarotti \& Spada, 2009; Dahlgaard-Park \& Dahlgaard, 2007; Kwok \& Tummala, 1998; Mohammad, Mann, Grigg, \& Wagner, 2009, 2011; Pellissier, 2009; Sharma \& Kodali, 2008). The organizations require practical and detailed guidance to achieve operational excellence (Sharma \& Kodali, 2008).

Small and medium enterprises (SMEs) have been recognized as the pillar of economic and social developments in many countries around the world (Halim and Zain, 2011). In Malaysia, SMEs are significantly contributed to the development of the Malaysian economy and the roles of SMEs are crucial in shaping the economic landscape of Malaysia in achieving high-income nation status by the year 2020 (Mahmud \& Hilmi, 2014). Moreover, manufacturing sectors are one of the important sectors to the economic development of the country. SMEs sector dominates the manufacturing sectors in Malaysia. The manufacturing sector is the largest contributor to total exports of the country and the second largest contributor to the gross domestic product (GDP). However, the total shares of Malaysia's manufacturing exports in the world market declined due to intense competition from emerging economies such as China, India and Vietnam (Eleventh Malaysia Plan, 2015). This is further supported by Malaysia's ranking in the Global Competitiveness Index $(\mathrm{GCl})$ which shown that Malaysia was ranked low in 2014.

The operational excellence is an important topic and has been an issue in both academia and industry. Review of the related literature indicates that the internal environmental factors are one of the core success factors towards operational excellence. The internal factors refer to the resources and capabilities of a firm (Shannahan, Shannahan, \& Alexandrov, 2010). Internal environmental factors comprised of two major elements namely hard factors (operation strategy, organizational structure and process management) while the soft factors (leadership style, organizational culture and human resource practices). The relationship and combination between hard and soft factors will lead the organizations towards the operational excellence (Dahlgaard-Park \& Dahlgaard, 2007; Ojha, 2015; Yew \& Ahmad, 2014). Additionally, the hard and soft factors are the influential elements towards excellence and have been recognized as success criteria behind excellence. The hard and soft factors also have been identified as an important internal resource and a strategy to increase business performance (Barney, 1991; Wernerfelt, 1984). 


\section{Literature Review Operational Excellence}

Various definitions of operational excellence can be found in the literature. Operational refers to an operating term that means to produce and deliver a product and achieve the mission while excellence means is an objective that must be fulfilled and sustained to stay successful (Mitchell, 2015). The deployment of operational excellence is gaining attention by the international industrialist who is concerned to improve the organization and increase productivity, agility and quality of an organization (Elouarat, Saadi, \& Kouiss, 2011). Operational excellence focused on operational performance and sustainable organizational performance. Operational excellence emphasizes on the performance of internal operations of a company where the excellence will prove quality improvement, flexibility improvement, delivery improvement, productivity improvement, cost and waste reduction (Susanti, Dachyar, \& Yadrifi, 2015).

Additionally, operational excellence also concerned the better performance and effectiveness in all dimensions of the organization. Operational excellence is not only about operation performance such as cost, time, quality, and flexibility metrics but also about sustainable performance such as handling people and resources efficiently to support the business growth (Dunggan, 2011). In order to enhance customers value, operational excellence does not only concern in the production process, consistency and reduce waste but also concern on creating value through interaction performance of employees, customers and supply chain (Miller, 2014).

Operational excellence involves the continuous improvement of the efficiency and effectiveness of the business processes. Operational excellence assures both organizational efficiency and effectiveness through reducing cost without decreasing volume of output and quality, reducing waste of time, raw materials, unnecessary processing, and energy used in transportation, storing, and operating plant (Booz Allallen, 2014). Moreover, operational excellence provides a competitive advantage to the organization by giving greater satisfaction to the customers. The organization achieves the operational excellence will lead them towards excellence in internal organizational processes of production and its delivery to the customers with a high score of satisfaction. The strength of internal organization then will reward the organization with the competitive advantages which in turn leads to the sustainability of the organization (Ojha, 2015).

The importance of the operational excellence to the organizations have been acknowledged in the literature. Treacy \& Wiersema (1997) stated that operational excellence is one of the disciplines and value propositions that organizations can choose to compete with their competitors in the business environment. Operational excellence is the design and management to maximize operating profit by continuous operational excellence in production and delivery system which can deliver customers the right value of products and services. The organizations that pursue the operational excellence will deliver value to the customers with a combination of speed, quality, price and ease of purchase and it will differentiate them in the market competition (Assen, 2011). 


\section{Internal Environmental Factors}

Previous studies on operational excellence have shown that the internal environmental factors are one of the core success factors towards operational excellence. The internal factors are the resources and capabilities of a firm (Shannahan et al., 2010). The internal factors refer to internal control that includes the policies, processes, tasks, behavior and other aspects of a company which taken together to facilitate and responds appropriately in the organization to achieve the company's objectives (Njaramba \& Ngugi, 2014). Internal environmental factors are consist of two major elements namely the hard factors and soft factors. The hard and soft factors are influential elements towards excellence and have been recognized as success criteria behind excellence. The hard and soft factors also have been identified as an important internal resource and a strategy to increase business performance (Barney, 1991; Wernerfelt, 1984). According to Barney(1991), the soft and hard elements will contribute competitive advantages and influences the performance. The soft and hard elements are comprised of internal resource which is an important element to achieve a sustained competitive advantage and superior performance that is operational excellence. In the present study, the hard factors refer to operation strategy, organizational structure and process management while the soft factors refer to transformational leadership style, organizational culture and human resource practices.

\section{Leadership Style}

Leadership has been recognized as a key driver for change, effective performance and organizational success (Zairi, 1999). According to Bass (1999), transformational leadership refers to the leader transform the followers from their self-interest through idealized influence (charisma), inspiration, intellectual stimulation or individualized consideration. It increases the follower's maturity level and concerns on the achievement, self- actualization, and the well-being of others, the organization, and society. Transformational leaders transform followers' attitudes, beliefs and values by motivating them to attain performance (Rafferty \& Griffin, 2004). In this study, transformational leaders refer to the leader change and influence the follower to achieve the operational excellence.

\section{Human Resources Practices}

Human resources (HR) are recognized as one of the most important assets in an organization where it can produce valuable benefits to the organization (Barney, 1991). Human resource practices refer to the organizational activities to manage weak human resources and enhance the resources towards organizational objectives (Pirzada, Hayat, Ikram, Ayub, \& Waheed, 2013). In the present study, human resource practices refer to activities and tools (such as recruitment and selection, training and development, performance appraisal, and compensation policy) that utilizing the individuals or peoples in the organization to achieve excellence.

\section{Organization Culture}

The organizational culture is one of greater effect on the performance and the operational excellence (Jaeger et al., 2014; Ojha, 2015; Romano, 2003; Yew, Ahmad, \& Baharin, 2013). In this study, the organizational culture refers to the involvement culture trait dimensions. Involvement 
cultural trait refers to the employees at all level of the organization are connected and work together in attaining the organizational mission and objectives. An effective organization that empowers their employees, build their organizations around teams and develop human capability at all levels will lead them to achieve the operational excellence. This is in line with Denison and Mishra (1995) who explained that the relationship between employee participation and empowerment would positively influence the organization to achieve superior organizational performance.

\section{Operation Strategy}

Operation strategy can be defined as the total pattern of decisions that shape the long-term capabilities of any operation and their contribution to overall strategy through the ongoing reconciliation of market requirements and operation resources (Slack \& Lewis, 2011). For this study, operation strategy refers to the pattern of decisions and actions driven to support the strategic goals established by the organization. The operation strategy consists of competitive priorities dimensions such as quality, cost, delivery and flexibility which are the key capabilities that the operations needed to compete in the businesses. The competitive priorities are the aspects of the operations performance that satisfy market requirements and operation objectives (Oltra \& Flor, 2010).

\section{Organizational Structure}

The organizational structure refers to the way in which the organization members are allocated according to their responsibilities and capabilities where procedures are carried out (Nahm, Vonderembse, \& Koufteros, 2003). For the present study, organizational structure refers to the formalization and decentralization dimensions of organizational structure in determining the way in which employees work by providing the task, responsibility and authority related to achieve excellence.

\section{Process Management}

According to Pritchard \& Armistead (1999), process management can be defined as a specific way to manage all aspects of the business and as a valuable perspective to adopt in determining organizational effectiveness. Process management is a set of tools and techniques for improving processes and a method for integrating the whole organization and it needs to be understood by all employees. Additionally, process management is one of the key areas that are important to improve the SMEs productivity of the basic elements to achieve the operational excellence in the complex environment (Lee, Lim, Ma, \& Xu, 2013; Pellissier, 2009).

\section{Methodology}

A pilot study was performed to ensure that the respondents will understand the questionnaires in answering questions. The pilot study was also conducted purposely to ensure the reliability, content validity, readability, wording, format and sequencing and clarity of questions. It is also used to evaluate the accuracy and appropriateness of the questions contained in the instrument and it also allowed the researcher to determine the length of time required for completing the questionnaire (Saunders, Lewis, \& Thornhill, 2009). 
INTERNATIONAL JOURNAL OF ACADEMIC RESEARCH IN BUSINESS AND SOCIAL SCIENCES Vol. 9, No. 2, Feb, 2019, E-ISSN: $2222-6990$ ๑ 2019 HRMARS

In this study, a pilot study was performed with a sample of 30 SMEs company by randomly selected which are located in Terengganu. This in line Hair, Black, Babin and Anderson (2010) who recommended that sample for piloting study is usually 5 to 30 respondents of the relevant population. Thus, this study was selected 30 SMEs company which represented by the managerial level who are closely linked to manufacturing operations to participate in the pilot study. These SMEs Company have been selected from the SME Business Directory which obtained from the SME Info Portal that is published by SME Corporation of Malaysia.

Moreover, a survey questionnaire was used in collecting data and was considered the most appropriate instrument for this study (Sekaran \& Bougie, 2010). A total of 30 questionnaires was personally delivered and collected by visited the respondents at their places. Respondents were given time to complete the questionnaire and submit it to the researcher. Content and face validity were conducted to ensure the validity of the items on the face of it measures the intended construct. In addition, this study used Cronbach's alpha coefficient which is the most common method to test the reliability (Sekaran \& Bougie, 2010). Finally, data collected were analyzed using the statistical package SPSS version 22 to test the reliability of the measures.

\section{Results}

\section{Descriptive Analysis}

A descriptive analysis of data was conducted to describe the internal environmental factors variables (leadership style, organizational culture, human resource practices, operation strategy, organization structure and process management) and operational excellence from the respondents' perspective. A descriptive analysis of the variables in this study was analyzed descriptively, by determining the statistical values of mean, standard deviation, minimum and maximum values for all the variables. The present study used five-point Likert scale criteria ranging from 1 "strongly disagree" to 5 "strongly agree" to measure respondents' feedback to all variables. Table 4.1 below shows the means, standard deviations, the minimum and maximum value of all variables.

Table 4. 1: Descriptive Statistics for the Variables

\begin{tabular}{|c|c|c|c|c|}
\hline Variables (N=30) & Min & Max & Mean & Std. Deviation \\
\hline Leadership Style & 3.25 & 4.50 & 3.8542 & 0.3913 \\
\hline Organizational Culture & 3.22 & 4.44 & 3.8778 & 0.3886 \\
\hline $\begin{array}{c}\text { Human Resource } \\
\text { Practices }\end{array}$ & 3.00 & 4.56 & 3.8333 & 0.4630 \\
\hline Operation Strategy & 3.00 & 4.55 & 3.8152 & 0.3702 \\
\hline Process Management & 3.44 & 4.44 & 3.8963 & 0.3032 \\
\hline Organization Structure & 3.00 & 4.63 & 3.7250 & 0.4470 \\
\hline Operational Excellence & 3.73 & 4.80 & 4.0400 & 0.2647 \\
\hline
\end{tabular}

Note: 1 = strongly disagree to 5 = strongly agree 
As shown in Table 4.1 above, the mean values for all variables were between 3.7250 and 4.0400 with standard deviations ranging from 0.2647 to 0.4630 . As a result, it found that the respondents were generally consistent in their opinions to the questions asked on the leadership style, organizational culture, human resource practices, operation strategy, process management, organization structure and operational excellence where the standard deviations of all the variables were not larger than three as recommended by Hair et al., (2010). In addition, the mean values indicated that the respondents appeared to have a moderately favorable perception of the leadership style, organizational culture, human resource practices, operation strategy, process management, organization structure and operational excellence. In other words, all variables are above satisfactory level.

\section{Validity Test}

In the present study, validity and reliability tests were performed to ensure that the instruments measured what it needed to measure. Reliability tests were used to test both validity and reliability to validate a measurement instrument. Validity used in this study was face and content validity. Face and content validity were conducted with panel experts and a small sample of respondents from selected SMEs Company and were given the questionnaires to validate it. The panel experts include two academicians from the local university and two SMEs managers were asked to give comments and feedback on the suitability of the adapted items to measure the construct. Based on their feedback, adjustment to questionnaire items was made to ensure awareness, wording and clarity of the questionnaire items.

\section{Reliability Test}

The reliability test was performed to evaluate the extent to which a set of items consistently measure the concept and to calculate the reliability of the items used in measuring each dimension. For the purpose of this study, Cronbach's Alpha was used to examine the reliability of the items. Table 4.2 shows the result of the reliability test for each variable. From the result of the reliability test, Cronbach's Alpha value for all of the measures used in the pilot study showed adequate reliability which ranged from 0.689 to 0.885 that considered acceptable reliability. This is in line with the criterion that a Cronbach 's alpha coefficient of 0.60 is considered average reliability, while a coefficient of 0.70 or higher indicates that the instrument has a high reliability standard (Hair, et al., 2010; Sekaran \& Bougie, 2011). Thus, it can be concluded that all the constructs measures used in this study are considered reliable. 
INTERNATIONAL JOURNAL OF ACADEMIC RESEARCH IN BUSINESS AND SOCIAL SCIENCES

Vol. 9, No. 2, Feb, 2019, E-ISSN: 2222-6990 C 2019 HRMARS

Table 4.2: Reliability test for the Variables

\begin{tabular}{|c|c|c|}
\hline Variables & Items & Cronbach's Alpha \\
\hline Leadership style & 8 & 0.850 \\
\hline Organizational culture & 9 & 0.689 \\
\hline Human resource practices & 9 & 0.838 \\
\hline Operation strategy & 11 & 0.816 \\
\hline Organizational structure & 8 & 0.885 \\
\hline Process management & 9 & 0.717 \\
\hline Operational excellence & 15 & 0.755 \\
\hline
\end{tabular}

\section{Discussion and Conclusions}

This study was conducted to examine the effect of internal environmental factors on operational excellence of SMEs manufacturing sector in Malaysia. The internal environmental factors in this study refer to the resources and capabilities of a firm. These factors consist of hard factors (operation strategy, organizational structure and process management) and soft factors (leadership style, human resource practices and organizational culture). This is in line with the Resource-based view (RBV) theory which explained that the resources and capabilities of the organization would determine the success of an organization (Barney, 1991; Wernerfelt, 1984).

Moreover, as mention earlier, this paper is aimed to determine the validity and reliability of the items measuring the internal environmental factors construct before conducting the actual survey. This will ensure the accuracy and appropriateness of the questions contained in the instrument. Additionally, the results of the pilot test indicated that the Cronbach's alpha values for all constructs are above 0.60 . Therefore, it can be concluded that all the constructs used in this study are reliable and no need to remove any item.

\section{References}

Abdul Wahab, M. H. A., Ismail, M., \& Muhayiddin, M. N. (2016). Factors Influencing the Operational Excellence of Small and Medium Enterprise in Malaysia. International Journal of Academic Research in Business and Social Sciences, 6(12), 285-297.

Ahmad, A. (2012). Macro-environment influences on health service strategy in Saudi private sector hospitals: An empirical investigation. International Business Research, 5(5), 49-64. http://doi.org/10.5539/ibr.v5n5p49

Assen, M. F. Van. (2011). Position paper - Operational Excellence for Services, 1-13.

Barney, J. B. (1991). Firm Resources and Sustained Competitive Advantage. Journal of Management, 17(1), 99-120. http://doi.org/10.1177/014920639101700108

Bass, B. M. (1999). Two decades of research and development in transformational leadership.

European Journal of Work and Organizational Psychology, 8(1), 9-32.

http://doi.org/10.1080/135943299398410 
INTERNATIONAL JOURNAL OF ACADEMIC RESEARCH IN BUSINESS AND SOCIAL SCIENCES

Vol. 9, No. 2, Feb, 2019, E-ISSN: $2222-6990$ ๑ 2019 HRMARS

Bolboli, S. A., \& Reiche, M. (2013). A model for sustainable business excellence: implementation and the roadmap. The TQM Journal, 25(4), 331-346.

http://doi.org/10.1108/17542731311314845

Cesarotti, V., \& Spada, C. (2009). A systemic approach to achieve operational excellence in hotel services. International Journal of Quality and Service Sciences, 1(1), 51-66. http://doi.org/10.1108/17566690910945868

Chen, C.-A. (2008). Linking the knowledge creation process to organizational theories: A macro view of organization-environment change. Journal of Organizational Change Management, 21(3), 259-279. http://doi.org/10.1108/09534810810874778

Dahlgaard-Park, S. M., \& Dahlgaard, J. J. (2007). Excellence - 25 years evolution. Journal of Management History, 13(4), 371-393. http://doi.org/10.1108/17511340710819606

Davis, M. M., Aquilano, N. J., Balakrishnan, J., \& Chase, R. B. (2005). Fundamentals of operations management. McGraw-Hill Ryerson.

Denison, D. R., \& Mishra, A. K. (1995). Toward a theory of organizational culture and effectiveness. Organization Science, 6(2), 204-223. http://doi.org/10.1287/orsc.6.2.204

Ekmekci, O. (2012). Reconfigured to be the Best: Leading Organizations to Excellence Through Quality Improvement. S.A.M. Advanced Management Journal, 77(4), 4-12.

Eleventh Malaysia Plan. (2015). Eleventh Malaysia Plan 2016-2020: Anchoring Growth on People.

Elouarat, L., Saadi, J., \& Kouiss, K. (2011). Teaching of operational excellence in Moroccan universities and high schools A major lever for a competitive Moroccan company. In 1st World Engineering Education (WEE) Flash Week, September 27-30, 2011, Lisbon, Portugal.

Hair, J. F., Black, W. C., Babin, B. J., \& Anderson, R. E. (2010). Multivariate data analysis (7th ed.). Prentice hall.

Halim, N. A., \& Zain, M. S. N. (2011). The Internationalization Theory and Malaysian Small Medium Enterprises ( SMEs ). International Journal of Trade, Economics and Finance, 2(4), 318-322.

Ifeanyichukwu, O. C. (2010). Organizational performance improvement in an oil producing facility in Nigeria through operational excellence. North-West University.

Jaeger, A., Matyas, K., \& Sihn, W. (2014). Development of an Assessment Framework for Operations Excellence (OsE), based on the Paradigm Change in Operational Excellence (OE). Procedia CIRP Conference on Manufacturing Systems Development, 17, 487-492. http://doi.org/10.1016/j.procir.2014.01.062

Kwok, K. Y., \& Tummala, V. M. R. (1998). A quality control and improvement system based on the total control methodology (TCM). International Journal of Quality \& Reliability Management, 15(1), 13-48.

Lansiluoto, A., \& Eklund, T. (2008). On the suitability of the self-organizing map for analysis of the 
INTERNATIONAL JOURNAL OF ACADEMIC RESEARCH IN BUSINESS AND SOCIAL SCIENCES

Vol. 9, No. 2, Feb, 2019, E-ISSN: $2222-6990$ ๑ 2019 HRMARS

macro and firm level competitive environment An empirical evaluation. Benchmarking: An International Journal, 15(4), 402-419. http://doi.org/10.1108/09574090910954864

Lee, A. J. L., Lim, R. Y. G., Ma, B., \& Xu, L. X. X. (2013). Improving productivity of the SMEs in Singapore - Case studies. 2013 IEEE International Conference on Industrial Engineering and Engineering Management, 73-77. http://doi.org/10.1109/IEEM.2013.6962377

Mahmud, N., \& Hilmi, M. F. (2014). TQM and Malaysian SMEs Performance: The Mediating Roles of Organization Learning. Procedia - Social and Behavioral Sciences, 130(10), 216-225. http://doi.org/10.1016/j.sbspro.2014.04.026

Miller, A. (2014). Redefining Operational Excellence : New Strategies for Maximizing Performance and Profits Across the Organization. The Journal of Applied Management and Entrepreneurship, 19(4).

Mitchell, J. S. (2015). Operational Excellence : Journey to Creating Sustainable Value. Wiley.

Mohammad, M., Mann, R., Grigg, N., \& Wagner, J. P. (2009). Selection of quality improvement initiatives: An initial conceptual model. Journal of Quality Measurement and Analysis, 5(2), 114.

Mohammad, M., Mann, R., Grigg, N., \& Wagner, J. P. (2011). Business Excellence Model: An overarching framework for managing and aligning multiple organisational improvement initiatives. Total Quality Management \& Business Excellence, 22(11), 1213-1236. http://doi.org/10.1080/14783363.2011.624774

Nahm, A. Y., Vonderembse, M. a., \& Koufteros, X. a. (2003). The impact of organizational structure on time-based manufacturing and plant performance. Journal of Operations Management, 21(3), 281-306. http://doi.org/10.1016/S0272-6963(02)00107-9

Njaramba, E. A. N., \& Ngugi, J. K. (2014). Influence of Internal Controls on Growth of Small and Medium Enterprises in the Errand Services Businesses in Nairobi County. International Journal of Current Business and Social Sciences, 1(1), 30-47.

Ojha, S. K. (2015). Operational Excellence for Sustainability of Nepalese Industries. Procedia - Social and Behavioral Sciences, 189, 458-464.

Oltra, M. J., \& Flor, M. L. (2010). The moderating effect of business strategy on the relationship between operations strategy and firms' results. International Journal of Operations \& Production Management, 30(6), 612-638. http://doi.org/10.5465/amj.2013.0599

Pellissier, R. (2009). Innovation in operational excellence in a complex environment. In PICMET: Portland International Center for Management of Engineering and Technology (pp. 811-825). http://doi.org/10.1109/PICMET.2009.5262041

Pirzada, D. S., Hayat, F., Ikram, A. A., Ayub, M., \& Waheed, K. (2013). Impact of Human Resources Management Practices on Turnover, Productivity and Corporate Financial Performance. European Journal of Business and Management, 5(10). 
INTERNATIONAL JOURNAL OF ACADEMIC RESEARCH IN BUSINESS AND SOCIAL SCIENCES

Vol. 9, No. 2, Feb, 2019, E-ISSN: $2222-6990$ ๑ 2019 HRMARS

Pritchard, J.-P., \& Armistead, C. (1999). Business process management - lessons from European business. Business Process Management Journal, 5(1), 10-35. http://doi.org/10.1108/14637159910249144

Rafferty, A. E., \& Griffin, M. A. (2004). Dimensions of transformational leadership: Conceptual and empirical extensions. The Leadership Quarterly, 15(3), 329-354.

Romano, K. W. (2003). The Influence of Organizational Culture, Leadership, and Structure on Operational Effectiveness in the Aerospace Industry. University of Phoenix. Retrieved from http://onlinelibrary.wiley.com/doi/10.1002/cbdv.200490137/abstract

Saunders, M., Lewis, P., \& Thornhill, A. (2009). Research methods for business students (5th ed.). Prentice Hall.

Sekaran, U., \& Bougie, R. (2010). Research methods for business: A skill building approach (5th ed.). United Kingdom: John Wiley \& Sons Ltd.

Shannahan, K. L. J., Shannahan, R. J., \& Alexandrov, A. (2010). Strategic Orientation and Customer Relationship Management: A Contingency Framework of CRM Success. Journal of Comparative International Management, 13(1), 1-13.

Sharma, M., \& Kodali, R. (2008). Development of a framework for manufacturing excellence. Measuring Business Excellence, 12(4), 50-66. http://doi.org/10.1108/13683040810919962

Shehadeh, R. M., Zu'bi, M. F., Abdallah, A. B., \& Maqableh, M. (2016). Investigating Critical Factors Affecting the Operational Excellence of Service Firms in Jordan. Journal of Management Research, 8(1), 157-190. http://doi.org/10.5296/jmr.v8i1.8680

Slack, N., \& Lewis, M. (2011). Operations strategy (Third Edit). Pearson Education Limited.

Susanti, Y. S. N., Dachyar, M., \& Yadrifi. (2015). Analysis of Factors that Support the Operational Excellence in Telecommunication-Supporting Companies. International Journal of Applied Engineering Research, 10(15), 35461-35465.

Treacy, M., \& Wiersema, F. D. (1997). The discipline of market leaders: Choose your customers, narrow your focus, dominate your market. Basic Books.

Wernerfelt, B. (1984). A Resource based view of the firm. Strategic Management Journal, 5(2), 171180. http://doi.org/10.1002/smj.4250050207

Yew, O. F., \& Ahmad, H. (2014). The Effect of Change Management on Operational Excellence moderated by Commitment to Change : Evidence from Malaysia. International Journal of Innovation and Applied Studies, 9(2), 615-631.

Yew, O. F., Ahmad, H., \& Baharin, S. (2013). Operational Excellence and Change Management in Malaysia Context. Journal of Organizational Management Studies, 2013, 1-14. http://doi.org/10.5171/2013.

Zairi, M. (1999). Managing excellence: leadership. The TQM Magazine, 11(4), 215-220. 
INTERNATIONAL JOURNAL OF ACADEMIC RESEARCH IN BUSINESS AND SOCIAL SCIENCES Vol. 9, No. 2, Feb, 2019, E-ISSN: 2222-6990 @ 2019 HRMARS

http://doi.org/10.1108/09544789910277288 